after many years of normal health. In such circumstances a diet containing the normal daily intake of gluten should be given, followed by a biopsy. If only a small amount of gluten is used it may produce mucosal lesions but without symptoms or objective evidence of malabsorption, and there will be difficulty in convincing the doubting patient of the importance of continuing on a strict diet. Patients who abandon dietary treatment completely should be told of the risks. Women should be advised to return to the diet during pregnancy.

1 Burke, V., Kerry, K. R., and Anderson, C. M., Australian Paediatric Fournal, 1965, 1, 147.

2 Stanfield, J. P., Hutt, M. S. R., and Tunnicliffe, R., Lancet, 1965, 2, 519. 3 Behar, M., in Diseases of Children in the Sub-tropics and Tropics, ed. D. B. Jelliffe. London, Edward Arnold, 1970.

4 Santiago-Borrero, P. J., Maldonado, N., and Horta, E., Fournal of Pediatrics, $1970,76,470$.

6 Weinstein, W. M., Brow, F. R., Parher, F., and Rubin, C. E., Gastroenterology, 1971, 60, 362 .

- Anderson, C. M., in Modern Trends in Paediatrics, vol. 3. ed. J. Apley, p. 216. London, Butterworth, 1970.

7 Friedman, M., and Hare, P. J., Lancet, 1965, 1, 521.

Schenk, E. A., Klipstein, F. A., and Tomasini, J. T., American fournal of Clinical Nutrition, 1972, 25, 1080.

- Sprinz, H., et al., American fournal of Clinical Pathology, 1962, 38, 43.

10 England, N. W. J., and O'Brien, W., Gut, 1966, 7, 128.

11 Russell, P. K., Aziz, M. A., Ahmad, N., Kent, T. T., and Gangarosa, E. J., American Fournal of Digestive Diseases, 1966, 11, 296.

12 Lindenbaum, J., Jamal Alam, A. K. M., and Kent, T. H., British Medical

13 Heurnal, 1966, 2, 1616. Pediatrics, 1967, 40, 345 .

14 Lamy, M., Frezal, J., Polonovski, J., Druez, G., and Rey, J., Pediatrics, 1963, 31, 277.

15 Peterson, J. C., and Kampmeier, R. H., American fournal of the Medical

Sciences, $1951,221,543$.
Aust, C. H., and Smith, E. B., American fournal of Clinical Pathology, $1962,37,66$.

17 Crocker, A. C., Vawter, G. F., Neuhauser, E. B. D., and Rosowsky, A., Pediatrics, 1965, 35, 627.

18 Kahana, D., Berant, M., and Wolman, M., Pediatrics, 1968, 42, 70.

19 Sheldon, W., Pediatrics, 1959, 23, 132.

20 Walker-Smith, J., Archives of Disease in Childhood, 1970, 45, 523.

21 Hamilton, J. R., and McNeill, L. K., fournal of Pediatrics, 1972, 81, 88.

22 Hamilon, J. R., and McNeill,

${ }_{23}^{22}$ Gough, K. R., Read, A. E., and Naish, J. M., Gut, 1962, 3, 232

24 Cooke, W. T., in Coeliac Disease, ed. C. C. Booth and R. H. Dowling, p. 11:8. London, Churchill, Livingstone, 1970.

\section{Diagnosis of Thyrotoxicosis}

The diagnosis of thyrotoxicosis is rewarding to both doctor and patient, for the treatment is specific and usually effective. In florid cases it should be obvious and not require confirmation by specific tests of thyroid function. A physician well versed in thyroid disease will also recognize most cases of intermediate severity on clinical grounds alone and may not need any confirmatory tests. Yet these will often be done if only to convince sceptical colleagues or to provide objective data for those who may have to deal with the patient in future.

At the lower end of the scale of clinical severity and in atypical cases we all come to rely increasingly on tests of thyroid function. ${ }^{1}$ But it should be borne in mind that such tests are liable to interference by many factors unconnected with the gland itself, and that they are just as subject to misinterpretation as are the clinical findings. They may, for instance, be altered if the patient has taken iodine in some form, such as clioquinol (Entero-Vioform) or radio-opaque media. Whether the patient is pregnant or on an oral contraceptive must be considerd. So must the possibilty of triiodothyronine thyrotoxicosis ${ }^{2}$ due to excessive secretion of triiodothyronine but not of thyroxine, in which the conventional tests of thyroid function are normal.
Despite the limitations of these tests there are types of cases in which clinicians have come to depend on laboratory support for the diagnosis, the more so if they are relatively inexperienced in this field. One of the commonest areas of diagnostic confusion lies in the distinction between thyrotoxicosis and those anxiety states in which nervous or cardiovascular symptoms predominate. The thyrotoxic patient, often warm and losing weight despite a good appetite, is usually fidgety and hyperkinetic, and her tachycardia is accompanied by a hyperdynamic circulation. The pulse pressure is increased, with a fall in diastolic and a rise in systolic blood pressure. This is reflected by an increase in peripheral circulation and of pulsation of the forearms as felt when they are gripped. Patients with an anxiety state are seldom hyperkinetic and despite their tachycardia usually have a normodynamic circulation. Sometimes, however, the distinction can be d:fficult, especially if eye signs are absent and there is no significant goitre. One then has to rely on such tests as the protein-bound iodine (PBI) and early (4-hour) uptake of radio-iodine (iodine-131). It must be remembered that the first test if positive is invalid in patients who are pregnant or on oral contraceptives. This is because oestrogens will raise the thyroxine-binding plasma proteins, whereas the level of free thyroxine, which is the active hormone, remains normal. Measurement of the free thyroxine index, ${ }^{3}$ though not yet a generally available test, may overcome this difficulty as well as that caused by exposure to iodine-containing compounds.

The rext type of case in which diagnosis may be difficult is the elderly thyrotoxic person. She is usually thin and without eye signs and may be apathetic. The disease may have smouldered on for several years before the onset of auricular fibrillation or congestive heart failure brings it to a head. Thyrotoxicosis should be suspected when the tachycardia of auricular fibrillation yields poorly to digitalization. A nodular goitre, often small, is usually palpable in the neck, and the PBI is raised. From the elderly patient's point of view this is the least troublesome investigation, though measurement of the uptake of iodine-131 in the neck is equally helpful in confirming the diagnosis.

In thyrotoxic patients who have already been treated by subtotal thyroidectomy or iodine-131 it is sometimes difficult to decide whether relapse has occurred or an anxiety state has supervened. Some of the clinical criteria for this decision have already been mentioned. Measurement of the PBI is probably the best confirmatory test, because the uptake of iodine-131 is often high, not because of thyrotoxicosis but because of a rapid turnover of iodine by a thyroid remnant functioning at maximal capacity to maintain a normal level of plasma thyroxine. Patients with a solitary, overproductive nodule of the thyroid, which suppresses activity in the rest of the gland, are often euthyroid, but they may eventually drift into thyrotoxicosis, which is apt to be mild. If suspected, this can be confirmed by finding a raised PBI.

The exophthalmos of Graves's disease can occur without thyrotoxicosis and may at first be unilateral. Having established by means of a test of PBI or iodine-131 uptake that the patient is euthyroid, the triiodothyronine (T-3) suppression test ${ }^{4}$ may confirm the diagnosis. If the uptake of iodine131 is not suppressed by a six-day course of triiodothyronine, unilateral exophthalmos is probably of endocrine origin and not due to a retro-orbital tumour or granuloma.

A new dimension has been introduced into the diagnosis of thyroid disease by the discovery of T-3 thyrotoxicosis. ${ }^{2}$ This is characterized by excessive secretion of triiodothyro- 
nine. The secretion of thyroxine $(\mathrm{T}-4)$ is normal, though later it may become excessive. It is thought that this disordered pattern of secretion may be due, in some cases at least, to iodine deficiency. The patient is clinically thyrotoxic, but the conventional tests of thyroid function are normal. A firm diagnosis can be made only by direct measurement of $\mathrm{T}-3$ and $\mathrm{T}-4$ in the plasma. These techniques are not yet generally available, but a failure to suppress uptake of iodine-131 by the $\mathrm{T}-3$ test $^{4}$ will support the diagnosis.

\footnotetext{
1 Daviss, A G., British Medical fournal, 1972, 2, 206.

2 Hollander, C. S., and Shenkman, L., British Fournal of Hospital Medicine, $1972,8,393$.

3 Harvey, R. F., Lancet, 1971, 2, 230.

4 Burke, G., American fournal of Medicine, 1967, 42, 600.
}

\section{Profits from Drugs}

Critics of the pharmaceutical industry have been given fresh ammunition by the publication of the report ${ }^{1}$ of the Monopolies Commission on Roche Products' tranquillizers chlordiazepoxide and diazepam (see p. 189). The commission found that the level of the company's profits had been "unjustifiable" and the Government is to use its powers under the monopolies legislation to compel the company to cut its prices.

The relationship between the Department of Health in its role as customer and the pharmaceutical industry has never been easy. Under the Voluntary Price Regulation Scheme the Department negotiates drug price levels with the manufacturers, and the scheme requires the submission of annual financial returns by the companies to provide a basis for agreement on the reasonableness of profits. Roche Products has always declined to take part in the voluntary scheme, and indeed has argued that the scheme is a form of excess profits tax. Though it had negotiated some repayments to the Department in the late 1960s, the company has refused to discuss prices since 1970. This attitude seems to have been a reaction to the Government's use of powers to grant compulsory licences to other firms to manufacture and sell drugs on which Roche held patents. The Department had, in the company's view, created conditions which made negotiations impossible, and this impasse led to the reference to the Monopolies Commission. The Roche parent company based in Switzerland refused to give the Monopolies Commission information on its world-wide sales and research costs, so that the commission's figure for the profits from the sale of the two drugs in the United Kingdom of $£ 25$ million over seven years is its own estimate. Roche claims that its prices in Britain are only half the world average prices for its drugs, but the commission argues that the company nevertheless makes higher profits than do comparable British-based firms.

What is not disputed is that Roche has an outstanding record of production of drugs valuable to medicine. The safety and freedom from side effects of the benzodiazepine tranquillizers have made it possible for doctors to stop prescribing barbiturates for many indications. More recently Roche has pioneered production of levodopa despite the lack of patent protection. If the company's profits have been high at least its research has been productive. Indeed Roche claims that it has never paid more than $2 \%$ of its turnover to its shareholders, the bulk of its profit being reinvested in long-term research.

Clearly it is reasonable for a Government to try to keep down the prices paid by the N.H.S. for its drugs; but there are now three ways in which it can interfere with the operation of normal market forces. The voluntary pricing scheme allows the Government to assess what are "reasonable" profits; the patents legislation allows the Government to grant licences to rival manufacturers to compete with the firm that developed a drug; and now the Roche incident has shown that if the Government is still dissatisfied it can in certain circumstances go to the Monopolies Commission for a recommendation for compulsory price cuts. This complex system of restraints is likely to cause ill-feeling within the pharmaceutical industry, which is heavily dominated by international companies. For these fore:gn-based firms the British market represents a very small proportion of their activities, and it would be unfortunate if relations between them and the Department of Health deteriorated. The present system of price control is clearly cumbersome and some companies at least resent the Government's intrusion into their internal financial affairs. There is no easy compromise between the view that "excess" profits should not be made out of illness and the free enterprise attitude that argues that prices and profits should be determined by what the market will bear. If either Government or industry pushes too hard the result could be disastrous for pharmaceutical research in Britain. Perhaps the time has come to take another look at the arrangements for determining drug prices in an attempt to find a more acceptable system.

Thn Mnnonnlies Commission. Chlordiazepoxide and Diazepam. London, H.M.S.O., 1973.

\section{Gallstone Composition}

The introduction of new analytical techniques has provided interesting information about the composition of gallstones. A quantitative microanalytical method has been recommended, ${ }^{1}$ but in Britain much of the new information derives from the work of June Sutor and her colleagues, who rely on $x$-ray diffraction technique. This identifies the crystalline substances in a gallstone, ${ }^{2}$ but the method has the disadvantage that amorphous material such as bile pigment and glycoprotein cannot be identified.

The main component in gallstones from the western hemisphere is cholesterol, though other crystalline compounds can be identified, among them calcium carbonate, calcium phosphate, and calcium palmitate. ${ }^{3}$ It is only since 1970 that calcium palmitate has been recognized as a component of gallstones other than from Japan. ${ }^{4}$ Indeed it is the fourth most abundant compound in stones from patients in the West. ${ }^{3}$ In a recent study of 31 patients A. G. A. Cowie and his colleagues found two patients who harboured pure calcium palmitate stones, but such stones must be regarded as rare, amounting to between 0.02 and $0.07 \%$ of all gallstones studied. 35

An awareness of the precise chemical composition of gallstones will lead to a more accurate classification. In addition it is possible that this knowledge could provide an answer to 